\title{
Effect of Vitamin E on Haematological Parameters in Albino Rats Treated with Gasoline
}

\author{
M. I. George and A. O. Adegoke* \\ Department of Medical Laboratory Science, Rivers State University of Science and Technology, \\ Port Harcourt, Nigeria
}

Received 20 May 2011, accepted in final revised form 6 April 2012

\begin{abstract}
This study was carried out to ascertain the antioxidant properties of vitamin $\mathrm{E}$ on haematoxicity caused by gasoline in albino rats using the haemoglobin and white cell count as indices. Thirty-five rats fed diet containing 1000iu of vitamin E per 100mg of feed for 2 weeks (to saturation) prior experiment were injected gasoline intraperitoneally while symptoms of toxicity and haematological parameters were monitored. The result showed that feeding on vitamin $\mathrm{E}$ diet increased the haemoglobin concentration while decreasing the elevated white cell count observed in gasoline treated rats, thereby conferring some protection against gasoline on the rats. The study also showed dose dependent reduction in haemoglobin concentration and increase white cell count in gasoline treated rats compared with increase haemoglobin and decrease white cell count in vitamin E treated rats. There was significant increase in haemoglobin concentration and decrease white cell count of vitamin E treated rats when compared with gasoline treated rats. This suggests that vitamin E conferred some protection on the rats against the haematotoxic effect of gasoline. Therefore feeding on diet containing vitamin E could help reverse the effect of gasoline intoxication in the body since it acts mainly as an antioxidant.
\end{abstract}

Keywords: Gasoline; Haematoxicity; Intraperitoneal; Vitamin E

(C) 2012 JSR Publications. ISSN: 2070-0237 (Print); 2070-0245 (Online). All rights reserved. doi: http://dx.doi.org/10.3329/jsr.v4i2.7670 $\quad$ J. Sci. Res. 4 (2), 437-444 (2012)

\section{Introduction}

Automotive gasoline is a generic term used to describe volatile petroleum fuel used primarily in internal combustion engines. Gasoline is a product of the fractional distillation of crude petroleum. It contains over 500 saturated and unsaturated hydrocarbons which have aliphatic, aromatic or branched chains. The hydrocarbons may have between 3 to 12 carbons and a boiling point range from $30^{\circ} \mathrm{C}$ to $220^{\circ} \mathrm{C}$ at atmospheric pressure [1] and specific gravity of $0.74 \mathrm{~g} / \mathrm{cm}$. Ingestion of gasoline is more hazardous than inhalation because gasoline has low surface tension and can easily be aspirated into the respiratory tract by vomiting [2]. Gasoline can be either the leaded or

\footnotetext{
*Corresponding author: bayoadeghq@yahoo.com
} 
unleaded type. Many of the harmful effects seen after exposure to gasoline are due to the individual chemicals in the gasoline mixture, such as benzene and lead. Inhaling or swallowing large amounts of gasoline can cause death and high concentration of gasoline is irritating to the lining of the stomach when swallowed [3]. Gasoline has been shown to cause dose dependent decrease in haemoglobin concentration and white blood cell counts $[3,4]$.

Antioxidants are molecules, which interact with free radicals and terminate the chain reaction before vital molecules are damaged. They donate an electron to stabilize a free radical. Antioxidants have long been known to reduce the free radical mediated oxidative stress caused by elements and compounds in the environment [5,6]. Vitamin E is synthesized by plants and is an antioxidant that protects all membranes and other fatsoluble parts of the body, such as low-density lipoprotein cholesterol, from damage. Some of the food sources of vitamin E include alfalfa sproats, avocado, bee pollen, carrot, chickweed, cumfrey root, dadelion root, garlic, greens (leafy), lemon grass, marsh mallow and mushrooms. Others include sunflower seeds and sunlight. Vitamin E is absorbed from the intestine through lymph. It circulates through the body plasma in associations with beta-lipoprotein. Vitamin $\mathrm{E}$ has been used in connection with the following conditions like anemia, burns, epilepsy, immune function for elderly people, intermittent claudication, rheumatoid arthritis, tardire dyskinesia, alzheimer's disease, angina, atherosclerosis, bronchitis, cold sores, down's syndrome, dysmenorrhea, heart attack, leukoplakia, osteoarthritis, Parkinsons disease, preclampsia, stroke, skin ulcers, infertility, age related cognitive decline etc [7]. Haemotological parameters assessed include haemoglobin levels and the white blood cells. Alterations in these indices are of diagnostic significance in routine clinical evaluation of state of health. The aim of this paper was to establish a possible protective role of vitamin $\mathrm{E}$ against gasoline induced changes in haematological indices using haemoglobin (Hb) and white cell count (WBC) (total and differential) as indicators.

\section{Materials and Methods}

\section{Test animals}

Eighty (80) male albino rats of $0.175 \mathrm{~kg}$ average weight were obtained from the Department of Pharmacology and Toxicology, University of Port Harcourt Animal House. The rats were fed ad libitum with rat pellets and water and acclimatize for two weeks prior to commencement of study in four separate groups. The petrol sample (gasoline) used in this study was obtained directly from AP filling station, University of Port Harcourt, near Port Harcourt. The vitamin supplements (E) used for the study was obtained from a pharmacy store, Ebus Pharmacy, Port Harcourt.

\section{Animal studies}

This group consisted of 20 rats, which were divided into 5 cages, each cage containing 5 rats. Preliminary study was carried out to determine $\mathrm{LD}_{100}$ and $\mathrm{LD}_{50}$ of gasoline by 
intraperitoneal administration of gasoline at 80, 160, 200 and $240 \mathrm{~g} / \mathrm{kg}$ while the last group was given normal saline to serve as control and the number of death monitored in all the groups and recorded. The $\mathrm{LD}_{50}$ was done by Arithmetic method of Karber [8].

Twenty five (25) albino rats divided into 5 groups of 5 albino rats each were administered with gasoline intraperitoneally at concentrations of 20,40, 80, and $160 \mathrm{~g} / \mathrm{kg}$ while the control rats in group 1 were administered with $0.9 \%$ normal saline. Signs and symptoms of toxicity due to gasoline were observed in the rats The rats were slaughtered and the blood collected into bottles containing ethylene diamine tetra (EDTA).

Thirty five albino rats divided into 7 groups for vitamin $\mathrm{E}$ were fed with diet containing 1000iu of vitamin E per 100mg feed for 2 weeks, after which the rats were administered with gasoline intraperitoneally at concentrations of 40, 80, 120, 160, 200 and $240 \mathrm{~g} / \mathrm{kg}$. The control rats in cage 1 were administered with $0.9 \%$ normal saline. Signs and symptoms of toxicity were observed. The rats were slaughtered and the blood collected into bottles containing ethylene diamine tetra acetic acid (EDTA) for haematological studies.

\section{Haematological studies}

The Haemoglobin ( $\mathrm{Hb}$ ) estimation was done by the cyanomethaemoglobin method using Drabkin's solution. Ferricyanide oxidizes the Fe (11) present in haemoglobin, oxyhaemoglobin and carboxyhaemoglobin into Fe (111) giving rise to Methaemoglobin which in the presence of cyanide ion produces cyanomethaemoglobin a stable red compound that is photometrically determined at 540nm. Haemoglobin estimation was done by pippetting $5 \mathrm{mls}$ of Drabkins solution into test tube and $0.20 \mathrm{ml}$ (20ul) of blood added, mixed and allowed to stand at room temperature for 10 minutes to allow complete conversion to cyanomethamoglobin. The absorbance of the solution was read at 540nm using Drabkin solution as blank. The value of unknown was extrapolated from the calibration curve already prepared.

Total white blood cell (TWBC): White blood cell diluting fluid (Turkes solution) contains a weak acid (glacial acetic acid) to lyse the red cell and a stain to stain the nucleus of the white cells [9]. One in twenty (1 in 20) dilution of blood was made using $2 \%$ gential acetic acid tinged with few drops of gentian violet, allowed to stand for complete destruction of red cells. The sample was loaded into already charged improved neubaur counting chamber and the white cells present in the four corner/mm2 areas were counted and multiplied by 50 .

White cell differential count: A thin blood smear film was made, labeled, allowed to dry and flooded with leishman stain for 2 minutes. The stain was diluted with buffered water for 8minutes.The stain was washed off with distilled water, air-dried and observed using oil immersion objective (x100). The cells were identified by their lobes and granules and counted.

\section{Statistical studies}

The biochemical data were subjected to some statistical analysis. Values were reported as Mean+SEM while student's t-test was used to test for differences between treatment 
groups using Statistical Package for Social Sciences (SPSS) version 16.A value of $P<0.05$ was accepted as significant.

\section{Results}

The result of this study showed dose dependent decrease in hemoglobin (g/dl) from $19.6+0.1$ at $0.00 \mathrm{~g} / \mathrm{kg}$ to13.2+0.1, 11.9+0.1, $11.0+0.1$ and $10.3+0.1$ at concentrations of 40 , 80,120 and $160 \mathrm{~g} / \mathrm{kg}$, respectively in gasoline treated rats while there was corresponding increase in vitamin $\mathrm{E}$ treated rats $20.0 \pm 0.1,20.1 \pm 0.1,19.2 \pm 0.1,18.2 \pm 0.1$ and $16.1 \pm 0.1$ which reduced to $15.4 \pm 0.1$ and $13.1 \pm 0.1$ at concentrations of 200 and $240 \mathrm{~g} / \mathrm{kg}$, respectively. The white cell count $\left(\times 10^{9} / 1\right)$ also showed dose dependent decrease in gasoline-treated rats with the counts 7.4+0.1, 10.6+0.1, 8.2+0.1, 5.3+0.1and $4.3 \pm 0.1$ at concentrations of $0,40,80,120$ and $160 \mathrm{~g} / \mathrm{kg}$ while the corresponding count in vitamin $\mathrm{E}$ treated rats had 7.6+0.1, 6.9+0.1, 6.3+0.1, 5.6+0.1 and 4.2+0.1 at concentrations of 0,40 , 80,120 and $160 \mathrm{~g} / \mathrm{kg}$ as shown below in Table 1 . Also concentration of 200 and $240 \mathrm{~g} / \mathrm{kg}$ had WBC of $4.2 \pm 0.1$ and $4.0 \pm 0.1$, respectively.

Table 1. Effects of vitamin E on heamoglobin and white cell count in rats treated with gasoline.

\begin{tabular}{cllllll}
\hline & \multicolumn{2}{l}{ Haemoglobin $(\mathrm{g} / \mathrm{dl})$} & \multicolumn{3}{c}{ White cell count $\left(\times 10^{9} / \mathrm{l}\right)$} \\
\hline $\begin{array}{l}\text { Conc. } \\
(\mathrm{g} / \mathrm{kg})\end{array}$ & $\begin{array}{l}\text { Gasoline } \\
\text { only }\end{array}$ & $\begin{array}{l}\text { Vitamin E } \\
+ \text { gasoline }\end{array}$ & $P$ value & $\begin{array}{l}\text { Gasoline } \\
\text { only }\end{array}$ & $\begin{array}{l}\text { Vitamin E } \\
+ \text { gasoline }\end{array}$ & $P$ value \\
\hline 0.00 & $19.6 \pm 0.1$ & $20.0 \pm 0.1$ & $>0.05$ & $7.4 \pm 0.1$ & $7.6 \pm 0.1$ & $>0.05$ \\
40.00 & $13.2 \pm 0.1$ & $20.1 \pm 0.1$ & $<0.05$ & $10.6 \pm 0.1$ & $6.9 \pm 0.1$ & $<0.05$ \\
80.00 & $11.9 \pm 0.1$ & $19.2 \pm 0.1$ & $<0.05$ & $8.2 \pm 0.1$ & $6.3 \pm 0.1$ & $<0.05$ \\
120.00 & $11.0 \pm 0.1$ & $18.2 \pm 0.1$ & $<0.05$ & $5.3 \pm 0.1$ & $5.6 \pm 0.1$ & $>0.05$ \\
160.00 & $10.3 \pm 0.1$ & $16.1 \pm 0.1$ & $<0.05$ & $4.3 \pm 0.1$ & $4.2 \pm 0.1$ & $>0.05$ \\
200.00 & & $15.4 \pm 0.1$ & & & $4.2 \pm 0.1$ & \\
240.00 & & $13.1 \pm 0.1$ & & & $4.0 \pm 0.1$ & \\
\hline
\end{tabular}

There was variation in the WBC differential count in gasoline treated rats $(31 \pm 0.1$, $60 \pm 0.1$ and $9 \pm 0.1$ ) for neutrophils (\%), lymphocytes (\%) and monocytes (\%) at $0.00 \mathrm{~g} / \mathrm{kg}$ while the neutrophils, lymphocytes and monocytes are $(47 \pm 0.1,53 \pm 0.1$ and $0 \pm 0.0)$, $(29+0.1,63 \pm 0.1$ and $8+0.1)(42+0.1,52+0.1$ and $6 \pm 0.1)$ and $(40 \pm 0.1,54+0.1$ and $6 \pm 0.1)$ at concentrations of $40,80,120$ and $160 \mathrm{~g} / \mathrm{kg}$, respectively. The vitamin E treated had the following for neutrophils, lymphocytes and monocytes $(32 \pm 0.1,60 \pm 0.1$ and $8 \pm 0.1$ ),

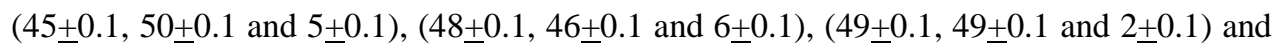
$(51 \pm 0.1,47 \pm 0.1$ and $2 \pm 0.1)$ at concentrations of $0.00,40,80,120$ and $160 \mathrm{~g} / \mathrm{kg}$ respectively while $(60 \pm 0.1,40 \pm 0.1,0 \pm 0.0)$ and $(50 \pm 0.1,50 \pm 0.1$ and $0 \pm 0.0)$ were 
neutrophils, lymphocytes and monocytes respectively at concentrations of 200 and $240 \mathrm{~g} / \mathrm{kg}$, respectively.

Table 2. Effects of vitamin $\mathrm{E}$ on differential white cell count in rats treated with gasoline.

\begin{tabular}{|c|c|c|c|c|c|c|c|c|c|}
\hline & Neutroph & ils (\%) & & Lymphoc & tes (\%) & & Monocyt & es (\%) & \\
\hline $\begin{array}{l}\text { Conc. } \\
\text { (g/kg) }\end{array}$ & Gasoline & $\begin{array}{l}\text { Vitamin E } \\
+ \text { Gasoline }\end{array}$ & $\begin{array}{l}P \\
\text { value }\end{array}$ & Gasoline & $\begin{array}{l}\text { Vitamin E } \\
+ \text { Gasoline }\end{array}$ & $P$ value & Gasoline & $\begin{array}{l}\text { Vitamin E } \\
+ \text { Gasoline }\end{array}$ & $\begin{array}{l}P \\
\text { value }\end{array}$ \\
\hline 0.00 & (2.3) & (2.4) & $>0.05$ & (4.4) & (4.6) & $>0.05$ & (0.6) & $(0.6)$ & $>0.05$ \\
\hline & $31 \pm 0.1$ & $32+0.1$ & & $60+0.1$ & $60 \pm 0.1$ & & $9+0.1$ & $8+0.1$ & \\
\hline 40.00 & (5.0) & (3.1) & $>0.05$ & (5.6) & (3.4) & $>0.05$ & $(0.0)$ & $(0.4)$ & $<0.05$ \\
\hline & $47 \pm 0.1$ & $45 \pm 0.1$ & & $53 \pm 0.1$ & $50 \pm 0.1$ & & $0 \pm 0.0$ & $5 \pm 0.1$ & \\
\hline 80.00 & (2.4) & (3.0) & $<0.05$ & (5.2) & (2.9) & $<0.05$ & (0.6) & $(0.4)$ & $>0.05$ \\
\hline & $29 \pm 0.1$ & $48 \pm 0.1$ & & $63 \pm 0.1$ & $46 \pm 0.1$ & & $8 \pm 0.1$ & $6 \pm 0.1$ & \\
\hline 120.00 & (2.2) & (2.7) & $>0.05$ & (2.8) & (2.7) & $>0.05$ & $(0.3)$ & $(0.2)$ & $<0.05$ \\
\hline & $42 \pm 0.1$ & $49 \pm 0.1$ & & $52 \pm 0.1$ & $49 \pm 0.1$ & & $6 \pm 0.1$ & $2 \pm 0.1$ & \\
\hline 160.00 & (1.7) & (2.1) & $<0.05$ & (2.3) & (2.0) & $<0.05$ & $(0.3)$ & $(0.1)$ & $<0.05$ \\
\hline & $40 \pm 0.1$ & $51 \pm 0.1$ & & $54 \pm 0.1$ & $47 \pm 0.1$ & & $6 \pm 0.1$ & $2 \pm 0.1$ & \\
\hline 200.00 & & (2.5) & & & (1.7) & & & $(0.0)$ & \\
\hline & & $60 \pm 0.1$ & & & $40 \pm 0.1$ & & & $(1.0) 0 \pm 0.0$ & \\
\hline 240.00 & & (2.0) & & & (2.0) & & & $(0.0)$ & \\
\hline & & $50 \pm 0.1$ & & & $50 \pm 0.1$ & & & $(1.0) 0 \pm 0.0$ & \\
\hline
\end{tabular}

Table 3. Overall effects of vitamin E on haematological parameters in rats treated with gasoline.

\begin{tabular}{lccc}
\hline \multicolumn{1}{c}{ Parameter } & Gasoline treated & Vitamin E treated & $P$ value \\
\hline $\begin{array}{l}\text { Haemoglobin (HB) } \\
\text { (g/dl) }\end{array}$ & $11.60 \pm 0.60$ & $17.00 \pm 1.00$ & $<0.05$ \\
$\begin{array}{l}\text { White blood count } \\
\left(\text { WBC) }\left(x 10^{9 / \mathrm{L}}\right)\right.\end{array}$ & $7.10 \pm 1.30$ & $5.20 \pm 0.50$ & $<0.05$ \\
Neutrophil (N) (\%) & $(2.81) 39.50 \pm 3.70$ & $(2.60) 50.50 \pm 2.10$ & $<0.05$ \\
Lymphocyte (L) (\%). & $(3.94) 55.50 \pm 2.50$ & $(2.4) 47.00 \pm 1.60$ & $<0.05$ \\
Monocyte (M) (\%) & $(0.5) 6.70 \pm 0.05$ & $(0.2) 2.50 \pm 0.80$ & $<0.05$ \\
Eosinophil (E) (\%) & $(0.0) 0.00 \pm 0.00$ & $(0.0) 0.00 \pm 0.00$ & $>0.05$ \\
Basophil (B) (\%) & $(0.0) 0.00 \pm 0.00$ & $(0.0) 0.00 \pm 0.00$ & $>0.05$ \\
\hline
\end{tabular}

Figures in brackets in columns 2 and 3 indicate absolute differential white cell count. 
The haemoglobin concentration of $17.00 \pm 1.00$ obtained in vitamin $\mathrm{E}$ treated rats increased significantly from $11.60 \pm 0.60$ while the WBC showed significant reduction with 5.20 \pm 0.50 in vitamin E compared with $7.10 \pm 1.30$ in gasoline treated. Also neutrophil count of $50.50 \pm 2.10$ in vitamin E was significantly different from $39.50 \pm 3.70$ while lymphocyte and monocyte count of $55.50 \pm 2.50$ and $6.70 \pm 0.05$ in gasoline treated were significantly different from $47.00+1.60$ and $2.50 \pm 0.80$ while there was no significant difference in eosinophils and basophils in the 2 groups as shown below in Table 3.

Table 4. Effects of vitamin E on Neutrophil : lymphocyte ratio in rats treated with gasoline.

\begin{tabular}{rll}
\hline $\begin{array}{l}\text { Conc. } \\
\text { (g/kg) }\end{array}$ & $\begin{array}{l}\text { Gasoline } \\
\text { Neutrophil :lymphocyte ratio }\end{array}$ & $\begin{array}{l}\text { Vitamin E } \\
\text { Neutrophil :lymphocyte ratio }\end{array}$ \\
\hline 0.00 & $1: 2$ & $1: 1.88$ \\
40.00 & $1: 1.13$ & $1: 1.11$ \\
80.00 & $1: 2.17$ & $1: 1$ \\
120.00 & $1: 1.24$ & $1: 1$ \\
160.00 & $1: 1.35$ & $1.09: 1$ \\
200.00 & & $3: 2$ \\
240.00 & & $1: 1$ \\
Overall & $1: 1.40$ & $1: 1.08$ \\
\hline
\end{tabular}

\section{Discussion}

There was a marked significant decrease of haemoglobin in all the groups, especially with the gasoline treated group. The result of this study showed that gasoline caused dose dependent decrease in haemoglobin concentrations in albino rats while feeding with vitamin E caused increase haemoglobin concentration. This is similar to report of chronic study by Dede et al. [10] using Bonny light crude oil, kerosene and gasoline which showed reduction in haemoglobin ( $\mathrm{Hb})$ and PCV levels in albino rats suggesting that long term exposure to petroleum samples could induce anemia. Wachukwu et al. [3], Dede et al. [4], Ayalogu et al. [11] and Uboh et al. [12, 13] also reported similar observations using gasoline. The reduction in haemoglobin level can be due to suppressive effect of petroleum sample on erythropoiesis [14] or as a result of haemolysis, which was caused by excessive destruction of erythrocytes. Reports of Christenssen et al. [15], Anderson, et al. [16], Sabo and Stegema [17], Connel and Miller [18], Krishna and Veena [14], Dheer et al. [19], Mohssen [20] all corroborated the result of the present study.

Vitamin E an antioxidant caused an increase in haemoglobin in this study. This is similar to study by Dede et al. [4] in which selenium; an antioxidant caused increase in 
haemoglobin concentration that was reduced by intraperitoneal injection of gasoline showing the antioxidant function of selenium. Antioxidants are type of molecules that neutralize harmful free radicals, produced through a chain of reactions [21], that damage living cells, spoil foods; degrade materials such as rubber, gasoline, lubricating oil. Antioxidants terminate these chain reactions through the removal of free radical intermediates and inhibition of other oxidation reactions [22]. This is why plants and animals maintain complex systems of multiple antioxidants, such as glutathione, vitamin $\mathrm{C}$, and vitamin E along with some enzymes like catalase, superoxide dismutase and various peroxidases.

Proliferation of white blood cells was higher in the gasoline treated rats and showed a dose dependent decrease in gasoline treated suggesting that gasoline suppresses the immune function. The vitamin $\mathrm{E}$ treated rats showed a dose dependent decrease which was quite minimal compared with the gasoline treated rats. This suggests that vitamin $\mathrm{E}$ as an antioxidant increased the immune function of the rats as shown with the white cell count. The use of antioxidants in pharmacology has been extensively studied, as oxidative stress might be an important part of many human diseases particularly stroke and neurodegenerative incidents [21]. Antioxidants, therefore, are routinely added to meals, oils, foodstuffs, and other materials to prevent free radical damage. Vitamin E has been reported to reduce enzymes induction in gasoline treated albino rats [23].

Differential leucocytes count showed a decrease in neutrophils and increase in lymphocytes in the gasoline treated group suggesting that gasoline is a stressor of the immune function which was reversed by treatment with vitamin E. There is no clear understanding of the variation in the neutrophil /lymphocyte ratio but the toxicity of petrol to haematopoetic cells in the bone marrow could be due to several of its metabolites that are formed in relatively highly concentrations and act in an additive or synergetic manner to disrupt a range of mechanisms that regulate blood cells formation. The treatment with vitamin $\mathrm{E}$ has reversed the haemotoxicity caused by gasoline by increasing the haemoglobin concentration while reducing the white cell count.

\section{References}

1. D. V. Hunt, The gasobol handbook (Industrial Press, 1981) ISBN 0-8311-1137-2.

2. C. D. Klaasen, Non metallic environmental toxicants: Heavy metals and heavy metal antagonists, In: Goodman and Gilman's The Pharmacological Basis of Therapeutics, $9^{\text {th }}$ edition, J. G. Hardman and I. E. Limbird (eds) (McGraw-Hill, New York, 1996).

3. C. K. Wachukwu, E. B. Dede, C. C. Ozoemena, and S. E. Amala, J. Med. Lab. Sci. 13 (1), 1 (2004).

4. E. B. Dede, C. P. R. Chike, and O. A. Adegoke, African J. Appl. Zool. Environ. Biol. 6, 128 (2004).

5. E. B. Dede and C. Ngawuchi, The Effect of Vitamin C on gasoline poisoned rats, In: Proceedings of Nigeria Environmental Society Conference, $13^{\text {th }}$ Annual General Meeting Bayelsa State (2003) p. 16.

6. E. B. Dede, C. K. Wachukwu, and C. Ngawuchi, The effect of Vitamin C on the histopathology of gasoline poisoned rats (Rattus norvegicus), In: Proceedings of the Nigerian Environmental Society Conference $13^{\text {th }}$ Annual General Meeting, Bayelsa State (2003) p. 16.

7. M. G. Traber, Vitamin E, In: Modern Nutrition in Health disease. M. E. Shils et al. (ed.) (Williams and Wilkins Publications, Baltimore, 1999) pp. 347-362. 
8. E. B. Dede and P. S. Igbigbi, J. Sci. Metasci. 111 (1), 1 (1997).

9. R. D. Sood, White blood cell count, In: Medical Laboratory Technology: Methods and Interpretation (Jaypee Brothers Medical Publishers, New Delhi, India, 1990) pp. 152-160.

10. E. B. Dede, N. M. Igboh, O. E. Ayalogu, P. C. Ofojekwu, I. S. Ezenwaka, and W. O. Alegbeleye, J. Appl. Sci. Environ. Management 6 (1), 60 (2002).

11. O. E. Ayalogu, N. M. Igboh, and E. B. Dede, J. Appl. Sci. Environ. Management 5 (1), 97 (2001).

12. F. E. Uboh, M. I. Akpanabiatu, P. E. Ebong, E. U. Eyong, and O. U. Eka, Acta Biol. Szeged. 49, 19 (2005).

13. F. E. Uboh, M. I. Akpanabiatu, I. J. Atangwho, P. E. Ebong, and I. B. Umoh, Acta Toxicol. 15 (1), 13 (2007).

14. A. G. Krishan and O. Veena, Environ. Contam. Toxicol. 25, 136 (1980). http://dx.doi.org/10.1007/BF01985501

15. M. G. Christensen, W. A. Brun, and E. P. Hunt, Toxicology Appl. Pharmacology, 23, 417 (1972). http://dx.doi.org/10.1016/0041-008X(72)90044-0

16. J. W. Anderson, J. M. A. Neff, B. Cox, H. E. Tatem, and G. M. Hightower, Crustaceans and Fish Marine Biology 27, 75 (1974).

17. D. T. Sabo and J. J. Stegeman, Some metabolic effects of petroleum hydrocarbons in marine fish, In: Physiological response of Marine Biota to Pollutants, F. J. Vembery (ed.) (Academic Press, New York, 1977) pp. 279-289.

18. D. W. Connel and G. J. Miller, Petroleum hydrocarbons in aquatic ecosystem behavior and effect of sublethal; concentrations: Part 1. Review Environmental Control 11, 37 (1980). http://dx.doi.org/10.1080/10643388009381685

19. J. M. S. Dheer, T. R. Dheer, and C. L. Mahagan, Biochemical J. fish Biol. 30, 577 (1987). http://dx.doi.org/10.1111/j.1095-8649.1987.tb05785.x

20. Mohssen, Hepatotoxicity Environ. Pollu. 96 (3), 383 (1997). PMid:15093404

21. N. M. Joseph, M. Sabharwal, A. Shashi, A. Mahor, and S. Rawal, Intl. J. Pharm. Sci. Res. 1 (1), 1 (2009).

22. H. Sies, Exp. Physiol. 82 (2), 29 (1997).

23. I. M. George, and O. A. Adegoke, J. Sci. Res. 3 (3), 641 (2011). http://dx.doi.org/10.3329/jsr.v3i3.7671 